\title{
Web review: Contrast media in radiology and imaging
}

\author{
IK Indrajit \\ Command Hospital (Air Force), Bangalore - 560 007, India
}

Correspondence: Dr I K Indrajit, Department of Radiodiagnosis and Imaging, Command Hospital (Air Force), Bangalore -560 007, India. E-mail: inji63@gmail.com

Few web-based sites related to contrast media in radiology and imaging, available at the moment, are reviewed below.

1. Introduction to Intravenous Radiographic Contrast is a concise summary of the subject by Romell Dhadha. Featured as a part of the Department of Radiology Short Clerkship: Lectures at University of Iowa, the material is available at http://www.radiology.uiowa. edu/Radshortclerkship/RadShortClkship/LectureNotes/ Dhada.htm.

2. A Simple Guide to the Basics of Contrast Media is available in the form of Guide notes at http:// www.e-radiography.net/contrast_media/contrast_ media_introduction.htm. The material includes iodinated intravascular contrast agents, barium sulfate, computerized tomography (CT) contrast agents, biliary contrast agents and reactions, allergic emergencies.

3. From eMedicine, comprehensive educative material on radiographic iodinated contrast media is obtainable at http://www.emedicine.com/radio/byname/contrastmedium-reactions-recognition-and-treatment.htm.

4. The webportal Chest Xray.com deals concisely with radiology contrast at http://www.chestx-ray.com/ Practice/Contrast.html. The following sections are covered: general, non-ionic vs ionic, risk factors, severity of reactions, renal toxicity, screening creatinine and treatment. Incidentally, the portal chest Xray.com at http://www.chestx-ray.com/ covers areas related to research, education, practice and resources.

5. Contrast Media in Diagnostic Radiology from the Textbook of Radiology at http://www.medcyclopaedia. com/library/radiology/chapter07.aspx is an up-to-date feature from Medcyclopaedia ${ }^{\mathrm{TM}}$. Medcyclopaedia ${ }^{\mathrm{TM}}$ is a "unique combination of a scientific library and a handy toolbox on the internet." In addition, the site features the complete online edition of The Encyclopaedia of Medical Imaging, the complete online edition of A Global Textbook of Radiology, GE Healthcare's Expanded
Medical Imaging Glossary, clinical cases for training purposes and a complete e-learning solution in normal imaging anatomy.

6. A Symposium on Ultrasound Contrast for Radiological Diagnosis titled Bubbles in Radiology - The State of the Art is available at http://www.sunnybrook. utoronto.ca/bubble/. The site requires a mandatory registration. Additionally, 'A Handbook of Contrast Echocardiography' authored by Harald Becher and Peter N Burns is available at http://www.sunnybrook. utoronto.ca/EchoHandbook/. Within this, there is an Interactive Glossary of Contrast Ultrasound at http://www.sunnybrook.utoronto.ca/EchoHandbook/ bookindex.htm.

7. Controversies and Consensus in Imaging and Interventions is a journal for medical imaging professionals, focusing on current issues in radiology, imaging and interventional radiology/cardiology and CT radiology. This website, sponsored by an educational grant from GE Healthcare, has a section on contrast media that is available at http://www.c2i2.org/contrast_ media.asp.

8. An educative supplement on Issues in Contrast and CT Angiography with Multislice CT is featured in Applied Radiology (Mar 2002), accessible at http://www. appliedradiology.com/backissues/issue.asp?ID=71, after a compulsory registration. The material covers important topics such as optimizing contrast use in multislice CT, fast $\mathrm{CT}$ in neurological imaging: contrast issues, contrast multiplies cardiac CT applications, CTA of extremities: new approaches to scanning, contrast use, new contrast administration protocols: safety considerations. A panel discussion is also available at the end.

9. Guidelines and manuals on the use of contrast media in radiology are issued periodically from reputed professional bodies. Currently available comprehensive references include

a. American College of Radiology Contrast 
Manual on Contrast Media version 6/2008, which is available at http://www.acr.org/ SecondaryMainMenuCategories/quality_safety/ contrast_manual.aspx.

b. ACR Practice Guideline for the Use of Intravascular Contrast Media, which is accessible at http://www. acr.org/s_acr/bin.asp?CID=541andDID=12241 andD OC=FILE.PDF.

c. European Society of Urogenital Radiology (ESUR) Guidelines on Contrast Media, available from http:// www.esur.org/fileadmin/Guidelines/ESUR_2007_ Guideline_6_Kern_Ubersicht.pdf.

d. Royal College of Radiology Standards for Iodinated Intravascular Contrast Agent Administration to Adult Patient, available from http://www.rcr.ac.uk/ docs/radiology/pdf/IVcontrastPrintFinal.pdf.

10. Review Articles/Citations on Contrast media in Radiology: There are numerous articles on contrast media in radiology available from various journals. From these, a handy 'must read' list of review articles on this subject, published in recent times and available online, is given below in Table 1.

\section{End piece}

The online database MR - Technology Information Portal (MR-TIP.com) was reviewed earlier in the Aug 2007 issue of this journal. Recently, a similar online database covering ultrasonography, titled UltraSound - Technology Information Portal is on offer at http://www.us-tip.com/ serv1.php?type=ldir.

US-TIP.com "is a global information resource aimed at people with professional interests in medical ultrasound technology for imaging and/or therapy." US-TIP.com, at its home page, links to a US-TIP Resource-Database that contains currently around 1600 entries. Within this are absorbing

Table 1: Review articles/citations on contrast media in radiology

\begin{tabular}{|c|c|c|c|c|}
\hline Sr no. & Article/citation title & Author (s) & Year & Online detail of journal with URL \\
\hline a) & $\begin{array}{l}\text { Guidelines for Contrast M edia from the European Society } \\
\text { of Urogenital Radiology }\end{array}$ & Thomsen HS & 2003 & http://ww w.ajronline.org/cgi/reprint/181/6/1463.pdf \\
\hline b) & $\begin{array}{l}\text { Contrast media and the kidney: European Society of } \\
\text { Urogenital Radiology (ESUR) Guidelines }\end{array}$ & $\begin{array}{l}\text { Thomsen H S, } \\
\text { Morcos SK }\end{array}$ & 2003 & http://bjr.birjournals.org/cgi/reprint/76/908/513 \\
\hline c) & Contrast Nephropathy: Review Focusing on Prevention & Maeder $M$ et al. & 2004 & http://content.onlinejacc.org/cgi/reprint/44/9/1763 \\
\hline d) & Contrast-induced nephropathy & Gleeson TG & 2004 & http://w w w.ajronline.org/cgi/reprint/183/6/1673 \\
\hline e) & $\begin{array}{l}\text { Frequently Asked Questions: Iodinated Contrast Agents } \\
\text { Current Practice Issues }\end{array}$ & Bettmann MA & 2004 & http://radiographics.rsnajnls.org/cgi/content/full/24/suppl_1/S3 \\
\hline f) & $\begin{array}{l}\text { Acute serious and fatal reactions to contrast media: our } \\
\text { current understanding }\end{array}$ & Morcos SK & 2005 & http://bjr.birjournals.org/cgi/reprint/78/932/686 \\
\hline g) & $\begin{array}{l}\text { Prevention of Contrast M edia-Induced Nephrotoxicity } \\
\text { after Angiographic Procedures }\end{array}$ & Morcos SK & 2005 & http://www.jvir.org/article/S1051-0443(07)60593-4/pdf \\
\hline h) & $\begin{array}{l}\text { Prevention of Contrast M edia-Induced Nephrotoxicity } \\
\text { after Angiographic Procedures }\end{array}$ & Morcos SK & 2005 & http://ww w.jvir.org/article/S1051-0443(07)60593-4/pdf \\
\hline i) & $\begin{array}{l}\text { Contrast-Induced Nephropathy: A Clinical and Evidence- } \\
\text { Based Approach }\end{array}$ & Tepel M etal. & 2006 & http://circ.ahajournals.org/cgi/reprint/113/14/1799 \\
\hline j) & Prophylaxis Strategies for Contrast-Induced Nephropathy & Pannu N etal. & 2006 & http://jama.ama-assn.org/cgi/reprint/295/23/2765 \\
\hline k) & $\begin{array}{l}\text { Nephrogenic systemic fibrosis: a serious late adverse } \\
\text { reaction to gadodiamide }\end{array}$ & Thomsen HS & 2006 & $\begin{array}{l}\text { http://ww w.ismrm.org/special/Editorial\%20Eur\%20Radiol\%20NSF. } \\
\text { pdf }\end{array}$ \\
\hline ।) & $\begin{array}{l}\text { Pharmacological prevention of serious anaphylactic } \\
\text { reactions due to iodinated contrast media: Systematic } \\
\text { review }\end{array}$ & Tramèr M R etal. & 2006 & http://www.bmj.com/cgi/reprint_abr/333/7570/675.pdf \\
\hline m) & $\begin{array}{l}\text { Important Properties of Contrast Media: Focus on } \\
\text { Viscosity }\end{array}$ & Voeltz M D et al. & 2007 & $\begin{array}{l}\text { http://vasculardiseasemanagement.com/files/docs/ } \\
\text { GuerbetM arch07] IC.pdf }\end{array}$ \\
\hline n) & What nephrologists need to know about gadolinium & $\begin{array}{l}\text { Penfield J G, Reilly } \\
\text { J r RF }\end{array}$ & 2007 & $\begin{array}{l}\text { http://ww w. nature.com/nrneph/journal/v3/n12/pdf/ncpneph0660. } \\
\text { pdf }\end{array}$ \\
\hline 0) & Contrast-induced nephropathy & $\begin{array}{l}\text { Wong GTC, Irwin } \\
\text { MG }\end{array}$ & 2007 & http://bja.oxfordjournals.org/cgi/reprint/99/4/474 \\
\hline p) & $\begin{array}{l}\text { Contrast media nephropathy- how to diagnose and how } \\
\text { to prevent? }\end{array}$ & Solomon $\mathrm{R}$ & 2007 & http://ndt.oxfordjournals.org/cgi/reprint/22/7/1812 \\
\hline q) & $\begin{array}{l}\text { Gadodiamide-Associated Nephrogenic Systemic } \\
\text { Fibrosis: W hy Radiologists Should Be Concerned }\end{array}$ & Broome DR et al. & 2007 & http://w w w.ajronline.org/cgi/reprint/188/2/586 \\
\hline r) & Iodinated Contrast M edia and Their Adverse Reactions & $\begin{array}{l}\text { Singh J, Daftary } \\
\text { A }\end{array}$ & 2008 & http://tech.snmjournals.org/cgi/reprint/36/2/69 \\
\hline s) & GE Healthcare Position Paper on NSF April 2008 & ES Cantor etal. & 2008 & http://images.ctisus.com/GE_whitepaper2.pdf \\
\hline
\end{tabular}


sections on UltraSound Technology, Knowledge 3D and 4D UltraSound, Contrast Agents, various examinations, History of UltraSound, Image Quality Artifacts, Probes Transducers and UltraSound Physics. Relevant to the topic of this web review, from the above two information portal sites, contrast agents is covered at http://www.mr-tip.com/serv1. php?type $=\mathrm{db} 1$ anddbs $=$ Contrast $\% 20$ Agents and http: $/ / w w w$. us-tip.com/serv1.php?type $=\mathrm{db} 1$ anddbs $=$ Ultrasound $\% 20$ Contrast $\% 20$ Agents.

EduRad at http://www.edurad.in/index.php is an online initiative aimed at integrating and improving the education of Radiologists by using a professional approach towards the organization of academic programs.Created by Dr. Bharat Parekh, Dr. Deepak Patkar and Dr. Jignesh Thakkar, the portal offers a wide range of web-based education for radiologists. After a mandatory registration, the website offers educative material on Case Reports, Image Gallery, Techno Watch, Classifieds, CME Events, Archives, Teaching Files, Radiology Learning Centre, Online Lectures and Past Conferences (Archives), Live Webcast-Interactive and DMRE (Part-I) lecture series on power point.

A Wiki is a special type of web site that enables a group of users to collectively edit, expand, revise, and create content. Wikipedia at http://www.wikipedia.org/ is a free encyclopedia of information created with a notable difference, in that, anyone can edit the information and therefore participate to create an online collaborative reference. What's more, the edited material is assessed for quality and verity by a "behind the scene" moderator group comprising of experts and voluntary professionals.

Medical Wikis are the medical equivalent of Wikipedia. They are hosted with an aim to offer comprehensive, veritable and up-to-the-minute information from a single point and that too on a large scale. Medical Wikis are emerging on the net as this List of Medical Wikis at http:// davidrothman.net/list-of-medical-wikis/ suggests. How far would they evolve and progress, what innovative features would they offer a decade from now, what are the advantageous spinoffs emerging from such websites and what is the endpoint in such websites are some of the hazardous questions that mystifyingly stare at us.

Nevertheless, when it comes to the discipline of radiology, the following Radiology Wikis are available at the moment:

a. RadiologyWiki at http://www.radiologywiki.org/wiki. This site has a radiology image search functionally similar to ARRS Goldminer, Yottalook and Google image search. Titled Ajax, this filtered radiology image search engine is available at http://www.radiologywiki.org/w/ index.php?title=AJAX_Search.

b. RadsWiki at http://www.radswiki.net/main/index. php?title=Main_Page. This site has many sections, including those on named fractures, radiology in movies, differential diagnosis and a list of signs in radiology.

c. Diagnostic Radiology Wikibooks is an open-content textbook collection at http://en.wikibooks.org/wiki/ Diagnostic_Radiology.

d. wikiRadiography at http://www.wikiradiography.com/ is an radiography resource on the web with sections on Applied Radiography written by M. J. Fuller, General Radiography, Computed Tomography, U/S, MRI and Mammography Homepages.

PMID: 19881115

Source of Support: Nil, Conflict of Interest: None declared. 